\title{
The idea of Judicial Pardon as Reform of Indonesian Justice System (Comparison of Judicial Pardon System Through Various Legal Instruments)
}

\author{
Aristo Evandy Alwan Barlian ${ }^{1}$, Bagas Heradhyaksa ${ }^{2}$ \\ \{email: aristoevandy26@yahoo.com ${ }^{1}$, email: bagasemail123@gmail.com² \\ Diponegoro University, Jl.Prof.H.Soedarto, S.H., Tembalang, Tembalang, Kota Semarang, Jawa \\ Tengah 50275 Indonesia $^{1}$ \\ National University of Malaysia, Bangi Selangor, 43600, Malaysia ${ }^{2}$
}

\begin{abstract}
The current criminal justice system in Indonesia does not have any guidance on excuses that can be done by judges. This is because there are only provisions on criminal acts and mistakes without including the objectives and principles of criminalization. Therefore many cases are not disconnected by public trust or punishment without regard to social values and material justice. Therefore, it is necessary to update the formula that can complement the legal deficiencies in Indonesia, namely the judicial pardon. The purpose of this study is to analyze the idea of judicial pardon in the penal system in Indonesia. Analysis of this research uses a comparative approach method. This means that this study examines all elements of the legal system in Indonesia that have a value of forgiveness in terms of culture, religion, and international comparison. As a result, it can formulate an acceptable and effective legal reform used in Indonesia. The result of this study found that there are five cultures and three values in a religion that has the concept of forgiveness. Also, seven countries have the authority of forgiveness in the courts of their country. In addition, there are 7 countries that have the authority to pardon in their courts. With the formulation of the idea of judicial pardon, it will make the criminal law system in Indonesia in the future more integral, flexible, humanist, progressive, and nationalist.
\end{abstract}

\section{Introduction}

The pattern of thought that every guilty person should be punished executed with the spirit of vengeance is disorientation in the criminal law of Indonesia, then what happens is an endless grudge. Criminal law should recognize and prioritize affection, as well as compassion, should animate every criminal law. The unlawful legal principle for you is the legal heritage of the criminal law of the Dutch East Indies, criminal should put forward the purpose in its system, and the purpose of punishment in criminal is nothing but realizing peace in human life. Punishment with Pardon is by the value of Pancasila based on Belief in God Almighty because the nature of Indonesian people in general, that is, forgiving each other. This Pardoness concept is in line with the existing religions and cultures in Indonesia. De Greiff has argued that there are reasons against punishment and favor of legal pardons [5]. Also, many other countries have incorporated the idea of pardons of judges within the penal system as well.

Many cases are inappropriate and even undermining public confidence so that shortterm prisons are considered wasteful for prisons, and punishment does not see the social value and material justice, let alone forgiveness only in the police and society. In this case, 
it is necessary to reform the formulation which can complement the legal deficiencies in Indonesia, namely the system of court forgiveness which has the purpose and principles in its implementation to reform the effective criminal justice system in Indonesia.

Given the diversity in beliefs and rules in every culture and religion, it is natural that this unitary state of the Republic of Indonesia has a uniform rule that is unified and codified to govern all Indonesian people from Sabang to Merauke. The uniformity of this rule or unification is done as a general rule applied to every citizen of Indonesia without exception. Since diversity surely is a thing that exists, it should not be an obstacle and be grateful instead, for it is a gift created by a perfect God.

The national legal product should be characterized by cultural (custom) and religious law in this country. If the national legal product is contrary to the law living in society, disharmony will happen in the law and foster mistrust of the national law. This matter can lead to a condition where the community will prefer to use customary law, or more people will perform vigilantism. This is in line with Marshall and Barclay opinion, which stated that law requires considering what people think and say it is and what they do to implement the meanings they conceive [8]. This is what happens if the national legal product is not suitable and not in line with the community values and still preserving the former colonial law products that tend to be liberal in no way characterized by the nation or even tears the human values in Indonesia.

Thus the future national legal product must be a law by the character / national identity of Indonesia, that is, Pancasila. The right product of the former Dutch colony should be changed as it is no longer appropriate with the times and nation of Indonesia's. In formulating the draft of national law, this nation should have a domestic legal product that stands on its own feet (Berdikari), by coordinating every rules that exist in culture and religion at the national stage and the comparison of international law as a foundation that will make the national law as law which is more perfect according to the person of the Indonesian nation.

\section{Methodology}

The approach method in this research is qualitative normative legal research. In normative legal research used several approaches, namely statute approach, the conceptual approach, and the comparative approach. The use of qualitative analysis methods normative is related to problems discussed in the comparative approach. Qualitative analysis of the data presented normative quantitatively, grounded in descriptive and predictive analysis. [1]

\section{Findings}

\subsection{The Value of Pardon Culture in The Traditional Criminal Law System}

Until now, dispute resolution through customary law is still widely used in addition to state law; culture law is considered more effective in solving community problems than state law that tends to be complicated by administration and application. Culture law provides an adequate settlement with the aim of peace and Pardons. Saguy and Stuart state that this occurred because of the process of feedback between culture and law [6].

At the $1975 \mathrm{UN}-\mathrm{V}$ Congress which took the topic of Prevention of Crime and the Treatment of Offenders, it was urged the importance of changes to the criminal legal system that is outdated and incompatible with reality and not rooted in the cultural values of society. This appeal is directed more at attempts to rethink the whole criminal policy (to 
rethink the whole of the criminal policy). [2]

The same way, it is clear that legal reform can also be done with an attempt to examine and eradicate the laws and community values influencing. It is widely spread in this country and very important to be reviewed. This thought also received support, as from Roeslan Saleh who stated:

"...Especially the culture law, especially the need for attention. There are things that can indeed be compiled and ultimately disorganized in such a way to apply as part of the whole criminal law, that is something that can be included in things that can negate the suspect/defendant's faults or things that ultimately justify the actions of the accused / defendant Which in the doctrine of the penal law is included in the doctrine against the material law and the doctrine of error".

As the identity of the nation, the existence of national law must have characteristics and characteristics in accordance with the philosophy and culture of the nation, let alone the provisions of the International and the Constitution of the 1945 Constitution guarantees the existence of culture law. Sudarto says: "No mistake, if to some extent can be said that the criminal law of a nation can be an indication of the nation's civilization." [3]

Based on the explanation above, it becomes clear that culture law in Indonesia has a basis for enforcement and therefore has the norms and sanctions should be obeyed by the community. Culture law can be categorized into written / unwritten legal rules including habits that arise, and are followed and adhered to continuously, even though the transition of generations that are passed down through the generations by indigenous peoples where the culture law grows and develops. One of the efforts to resolve the dispute that occurred in indigenous peoples is by conducting deliberation. In this research will be discussed the legal settlement of legal culture of Aceh, Baduy, NTT, Lampung, and Bali which can be the basis of the review in the formulation of the idea of judicial pardon in Indonesian criminal law system. Pedriana and Stryker (1997) showed how the general cultural values expressed in law mediate the effects of past laws on future laws [7].

The five customary criminal systems (Aceh, Baduy, Bali, NTT/Flores, and Lampung) have codification recorded in their customary rules. Besides these five customs, many different cultures in Indonesia have the value of forgiveness sourced from interviews but are not codified in their cultural histories such as the praise culture in Minangkabau and Dayak. Referring to some of the above culture settlement disputes, peace is the primary objective in the settlement through culture law to restore the damages caused by the conflict.

The value of forgiveness is also contained in every diplomatic process in conflict solving. Almost every case handled by culture with deliberation is a light matter which still has the possibility of being pardoned. By observing culture provisions, an idea that culture law is now more flexible and effective in resolving public affairs than the currently hard/absolute state courts. In this context, it is by Artidjo Alkotsar's statement [13]:

"The settlement of cases in customary law is always based on the settlement of cases, not on deciding cases as happened in European or Western law events. Thus, once there is a settlement in the culture case, the personal relationships, and kinship of the community of the indigenous peoples are maintained. Whereas in European or Western law, after the dispute of dispute by the court, then also the relationship of their disputed family".

Culture disputes such as theft, accidents, fraud, rape, fights, account payable, humiliation and so on are primarily resolved by deliberation, most of the disputes resolved 
by culture law are more effective than strict/absolute state laws which do not place peace Community. In line with Dellinger and Williams opinion that boundary lines between acceptable and unacceptable harassing behavior are drawn differently depending on the workplace culture [8]. Mild cases that can be resolved under culture law through permission are usually discontinued and passed on to state courts.

Settlement of disputes through culture law requires the similarity of attitudes and views of both parties to the dispute about how they will be settled. This is undoubtedly more soultouching and effective by fostering the pattern of initiatives from among the parties to mutual pardon with the impulse of recognition of mistakes and statements do not repeat again the act and accompanied the spirit to restore the damage of the perpetrators who make the settlement atmosphere more smoothly and loved than through the state court.

Ter Haar and Soepomo [10] explain that everything that goes against culture law is a moral violation of society because it can harm and damage the values of people's lives. The law applicable in the culture of this society is also known as the culture reaction, this custom reaction is an action or effort undertaken to restore and restore imbalances and disturbances that occur in the community

\subsection{The Concept of Pardoness Through The Perspective of The Religious Law System}

People have studied the teachings of religion in their daily life, and of course, they try to implement into their habit or daily. They tend to refer more to religious beliefs in deciding religion is perceived as the guideline of human life in the world. The peaceful decisionmaking by focusing on the settlement of disputes inappropriately is one of the closely related to religious teachings. Nurcholis Madjid states that religious understanding is the basis of behavioral control on every individual.

In cybernetic relations, religion will give control to the human cultural system is behaving, and become the public understanding that God created man to keep peace on earth. Understanding of the teachings of religion has a correlation that is manifested in the behavior of every society that holds its religion as a guide of life. So, Pardoness is one of the characteristics of a religious character in Indonesia upholding peace.

\subsection{Pardon in The Islamic Law System}

Islam bearing the concept ofRahmatan Lil 'alaminwhich teaches the ideas of the relationship of affection and not hurting human beings (Mu'amalat) and the whole of nature. The criminal-and-crime-oriented punishment system of criminal law is linked to "Qishaash and Diyat." The following description rests more on the issue of Pardoness and diyat issues instead of on the description of the party who is obliged to pay diyat because diyat is a "juridical consequence" of the existence of pardons. The analysis of qishaash is done because it is directly the sacred word/divine base (Allah SWT) which allows the emergence of pardons.

Al-Qur'an chapter Al Baqarah verse 178 said that:

"To those who believe, are required of you qishaash in respect of those who are slain; Free people with free men, slaves with servants, and women with women. So, whoever receives a pardon from his brother, let him (the forgiving) follow in a good way, and let (who is paid) to pay (diyat) to the one who gives the Pardon in a good way (also). That is a remission from your Lord and a mercy. Whoever exceeds the limit after that, so for him a harrowing punishment." 
The Word of Allah above opens the possibility of Pardoness, and it gives the consequences indicate. In the case of Pardoness, Islamic Criminal Law is very wise and purposed to uphold the value of humanism. The assertion by the heirs of the victim to the murderer to pay diyat (compensation) to the forgiving, containing the value of humanism implied in the word of Allah "follow in a good way."The victim's heirs can request Diyat payments in the right way, such as no urgent killer and the murderer should pay in the right way too, that is to say, not to delay. The value of humanism in Islamic Criminal Law is also spoken by Allah, in Al Baqarah verse 179; "In the case of qishaash is there (assurance of continuity) of life for you, people of understanding, that you are pious."

Also, Islam provides guidance in the Qur'an Pardoness written in several letters such as chapter Asy-Syuura and An-Nahl:

- $\quad$ Asy-Syuura verse 40:" And the reward of a crime is a similar crime, so whoever Pardon and does good is rewarded by Allah. He does not like those who do wrong".

- Asy-Syuura verse 42: "But be patient and forgiving people who actually (actions) such that included things that take precedence."

- An-Nahl (QS.16) verse 126: "And if you give back, then repay the same as the torment imposed upon you. However, if you are patient, it is better for those who are patient".

According to Syekh Mahmud Syaltut, pardons is the element of peace, ulul Amri (government) is given the right to Pardon when the guardian of blood still demands qishaash and Ali bin Abi Talib in NahjulBalaghah has stated that the most forgiving is the person who has the most ability to punish, in terms of This Islam gives the government the right especially to the judge to be able to Pardon. In theory, the government in the case of a judge is given the authority to Pardon, but the judge is also given the authority in the event of deciding the punishment which allows for the Pardoness by the judge.

Anas bin Malik once said that every qishaash case brought to the Messenger of Allah, he asked to be Pardon. The jurist also said, "Pardoness is better than peace and peace is better than qishaash." This means that the religious scholars of Islam are very precisely the existence of pardon for the realization of peace among peers, here it appears that our legal system must include the idea of Pardoness according to culture and religion that exist in the belief of the Indonesian nation.

Thus the pardon is imposed in the view of Islamic law is also punishment. Where a criminal can apologize and regret his actions that have harmed the victim, this gives a lesson that the offender can confess all his mistakes, while to admit the mistake is massive because people always feel right with what he does, even though the law regulates it and states that his actions are wrong.

In this case, to acknowledge that the act he was doing was wrong is indeed heavy especially if the one apologizing is nobody and do not have anything, in the eyes of Allah all the same, in front of Allah are equally creatures created Allah, in this case Has a value that is the lesson of honesty, and the field of chest recognizes the error, while the victim or his family to Pardon the person who has hurt it was heavy, this is a lesson for the chest to accept the reality and test of his life.

\subsection{Pardon in The Christian Law System}

Law of Love Jesus is the law which primarily is the core Jesus Christ's teachings contained in all three Synoptic Gospels are Matthew, Mark, and Luke. This Christian law teaches compassion through such Pardon concept [16]:

- $\quad$ Matthew 22:37-40; "Jesus answered him, "Love the Lord your God with all your heart and with all your soul and with all your minds." That is the first and great 
commandment, and the second is like: Love your neighbor as yourself. On these two commandments hang all the Torah law and the book of prophets."

- Matthew 6:14-15: "For if you Pardon people's guilt, your heavenly Father will also Pardon you. However, if you do not Pardon people, your Father will not Pardon your faults either."

- Matthew 18:21-22: "verse 21: Peter asks how many times he should Pardon his brother if he does what seven times, verse 22: "Jesus said to him no! I say unto you not until seven times, but unto seventy times seven times".

- $\quad$ Mark 11:25: " And if you stand to pray, Pardon if there is anything in your heart for someone so that your heavenly Father Pardons your faults."

- $\quad$ Luke 23:34: "Father, pardon them, for they do not know what they are doing. "

Matthew Bible 18:21-2, teaches Christians to address how people should act, Pardon or Pardon. The teachings of Christ can interpret in his letter that whenever anyone does wrong, it should be granted a pardon and not keep it where it will eventually arise into an endless grudge. The doctrine of Christ teaches his people that keeping the faults of others is a bitter root in our hearts, will be diseases, discomfort, isolation, and hatred towards that person.

This teaching of Jesus teaches to do more than apologize, that we Pardon. The word Pardon has a deeper meaning, i.e., forgetting, sincerely accepting all the faults of others and not remembering it. It is a hard thing to do. Jesus gives an example in the Bible verse of Mark 11:25, which is very easy for any Christian to understand. This verse means that if you do not Pardon, God will not Pardon you. This is a severe verse because, for Christians, God regards Pardoness as something significant, meaningful, and essential. This is one of the most excellent choices that can change a Christian's life.

Lukas 23: 34 Explains the history of Christianity with the crucified Isa Al-Masih sentenced to walk by the cross through many hills until covered with blood, even though he is slandered on guilty charges and cruelly punished for Christians, Jesus for Christians is a giver of peace and Pardoness because before he died With the penalty of the cross he mentions the last words as stated in Luke 23:34 by asking the father to Pardon the deeds of those who have punished him because they know nothing. The content of this letter of Luke is profound for the people of Christ for teaching that although Jesus is slandered and tortured, he remains forgiving because he knows those who punish him knows nothing. Therefore the philosophy of Pardoness is dominant for Christians in the last verse/word issued by Jesus.

Thus, apology and Pardoness are significant in the doctrine of Christ embodied in Matheus, Mark, and Luke, for the people of Christ to break the barrier between his people and god he must cleanse the heart through Pardoness. Christians always pray and apologize in the church, because if they cannot Pardon and apologize the relationship of Christians will be more disconnected with their Lord. This emphasizes that Christ's law of love in Pardoness is a fundamental doctrine for Christians because it has an associated relationship between the people and their god.

\subsection{Pardon in The Hinduism Law System}

Hindu law has similarities to the cultural system in Bali because Balinese culture is derived from the Hindu teachings of which the majority Hindu community. The teachings of Hinduism teach "Tri Hita Kerana," meaning harmonization, in realizing the harmonization of Hindus to purify to remove sin so that the guilty can be Pardon or accepted back in society. Pardon is identical with the chess doctrine of Bhakti Marga in Hinduism. Bhakti Marga is a teaching of love that is generally practiced by all people who know the teachings 
of "Tat tvam asi" or which means you are me, or vice versa. It is this doctrine that forms the basis of Hinduism to Pardon one another.

In Hinduism known name ksama which means forgiving or forgiving nature. Hindus have a forgiving and non-vindictive character. Being willing to Pardon others' faults is a very commendable stance in the meaning of ksama. Hindus are aware that making mistakes is a human act, meaning anyone can do it because no one can escape from mistakes. Therefore, being forgiving should always be the mindset of Hindus.

Sin arises from the act of rebellion to God. God has granted freedom of will to humanity, and the Vedic literature has given guidance in order to live on the path of the Dharma that wipes out sin. The Vedic God in Hinduism allows humanity to do repentance. Repentance in Hinduism is called prayascita, prayascita can be done with samskara ceremony (purification from the outside) but more importantly pure self-purification, through tapa, brata, yajna, and Kirti. In the books of Hindu Purana, Pardoness or consolation of $\sin$ (prayascita) is packaged in the form of Brata Sivaratri.

1. Sivaratri Kalpa 37, 7-8: “' Om ksantavyah kayiiko dosah ksantavyo vaciko mama ksantavyo manaso dosah, tat pramadat ksama-svamam" (Pardon sins even though they are really very evil, do dirty deeds, kill innocent, congregate and disrespectful teachers, kill babies in the womb, all errors are gone by doing Brata Sivaratri).

2. Manawa Dharmasastra V.109: Guiding mankind to purify themselves from cleansing the body with water, mind with truth, soul with tapa brata, then intelligence (buddhi) with actual knowledge (jnana).

The effort of Prayascita Tri Kaya by Brata Sivaratri is in line with the guidance of Lontar Agastya Parva which is Sivaistic. It mentions there are three ways to achieve tranquility and happiness, namely tapa, yajna, and Kirti. Tapa contains the meaning of selfcontrol for people doing yajna, and be they worshipers who love God. Loving God is not enough with yajna alone, but they must do service to other beings, as God's physical being. That ministry is called Kirti, sadhana, or seva. Those who run are believed to be the ones whom God loves, which in the end they will unite with Siva.

According to the above explanation, prayascita is as a form of a religiously magical fusion of sin, taught in the Vedas and its literature on Hinduism. Pardons in Hinduism can be done by first purifying by worshipers pleading for Pardoness to a worshiped deity. Hinduism believes in reincarnation, in the belief that one who is not one with nature and close to God will continue to live lost in a finite world cycle. Thus the purification of self by removing sin and giving peace to the people in order to maintain tranquility in Hindu teachings is the Pardoness and cleansing of the gods in order to be united with nature and get closer to his god.

\section{Conclusion}

They concluded that in the analysis of the study of this research, we had found 5 (five) legal cultures in Indonesia that have the value of forgiveness in the conventional criminal system such as Aceh, Lampung, Baduy, NTT, and Bali. The five customary criminal systems have codification recorded in their customary rules, besides these five customs there are many different cultures in Indonesia that have the value of Pardoness sourced from interviews but are not codified in their cultural histories such as the praise culture in Minangkabau and Dayak. The value of Pardoness is also found in various religious systems recognized in Indonesia as beliefs and guidelines of nation life as in Islam, Christianity, and Hinduism. 
That being said that it is natural for Indonesia to change its penal code in accordance with the culture and religion that lives in it so that the legal system in Indonesia is more civic, social, humane, justice, integral, flexible, humanist, progressive and nationalist according to the nation's character Pancasila by entering the idea of forgiveness as the goal And principles in providing future criminal decisions.

\section{References}

[1] J. Ibrahim, Theory and Legal Research Methodology Normative, Bayumedia Publishing, Surabaya, p.444. 2005

[2] B. N. Arief, Criminal policy (Rampai flower), Citra Aditya Bakti, Bandung, p. 117. 1996

[3] A. Abubakar, M. Syari'ah, "Settlement of Indigenous Criminal Cases in Aceh," Islamic law and Societyvol. XII number 23. p. 36. 2010.

[4] P. De Greiff, "Trial and punishment: pardon and oblivion." Philosophy \& Social Criticism, 22(3), p. 93-111. 1996.

[5] D. Melossi, "The cultural embeddedness of social control: Reflections on the comparison of Italian and North-American cultures concerning punishment." Theoretical Criminology 5 (4), p. 403-24. 2001

[6] P. Nicholas, and R. Stryker. "Culture wars 1960s style: Equal employment opportunityAffirmative action law and the Philadelphia Plan". American Journal of Sociology, Vol. 103 (3): p. 633-91. 1997.

[7] M. Anna-Maria, and S. Barclay. "In their own words: How ordinary people construct the legal world." Law and Social Inquiry, Vol. 28 (3). p. 617-28. 2003

[8] D. Kirsten, and C. Williams."The locker room and the dorm room: Workplace norms and the boundaries of sexual harassment in magazine editing”. Social Problems, Vol. 49(2), p. 242 57. 2003

[9] The book of Kuntara Rajaniti Megou Pak Tulang Bawang (Menggala), section 131 about law culture in Menggala, Lampung.

[10] Ter Haar. Law Culture Principle’s. 108. 1981 